\title{
The Real in the Magic: A Study of Magic Realism in Salman Rushdie's Haroun and the Sea of Stories (1990)
}

\author{
NUURZAHIRAH ALI \\ *AIMILLIA MOHD RAMLI \\ Department of English Language and Literature, International Islamic University Malaysia, \\ 53100 Kuala Lumpur, Malaysia \\ *Corresponding author: aimillia@iium.edu.my
}

Published online: 31 October 2019

To cite this article: Nuurzahirah Ali and Aimillia Mohd Ramli. 2019. The real in the magic: A study of magic realism in Salman Rushdie's Haroun and the Sea of Stories (1990). KEMANUSIAAN the Asian Journal of Humanities 26(2): 123-139, https://doi.org/10.21315/kajh2019.26.2.6

To link to this article: https://doi.org/10.21315/kajh2019.26.2.6

\begin{abstract}
While many studies have focused on Salman Rushdie's use of magic realism in his highly-acclaimed novels, the way it is employed in his children's fiction remains understudied. This paper, hence, attempts to fill in this gap by applying Anne Hegerfeldt's (2005)'s theoretical framework on magic realism onto its reading of Salman Rushdie's Haroun and the Sea of Stories (1990). This framework relies on five techniques or features namely: a realist mode of writing to describe fantastic events and characters, a marginalised focaliser, subverted scientific and historical discourses, a supernatural reality and finally, a literal manifestation of a figurative expression. This paper also suggests that Rushdie employs magic realism to undermine the realist narrative mode as well as scientific and historical discourses in order to present an alternative worldview that places narrative knowledge, gathered from stories with magical characters and events, as a legitimate source of knowledge regarding the world.
\end{abstract}

Keywords and phrases: magic realism, Salman Rushdie, children's fiction, narrative knowledge

\section{Introduction}

Magic realist children's fiction remains to this day one of the most understudied fields of research in children's literature. One possible reason could be the undesirable effect that magic realist stories are perceived to have on the child reader. In his seminal work The Uses of Enchantment (1976), Bruno Bettelheim applies a psychoanalytic framework onto his reading of fairy tales which, he argues, provide the child reader with harmless and acceptable ways of dealing with emotions, such as anger and jealousy. This happens when the child reader 
draws upon similarities between his real life problems and the predicaments faced by fantastical characters of his readings. The fact that the fairy tales, he argues, are set in the realm of fantasy enables the child reader to repress his emotions and project them onto the tales' fictional characters. This continues to happen until enough time has passed and the child reader becomes an adult who is able to overcome or deal with his problems in real life as he becomes more mature both physically and emotionally. Unfortunately, Bettelheim continues, stories that have improbable events and fantastical creatures in a realistic setting, such as those with magic realist features, cause the child reader to become confused when he strives to differentiate fantasy from reality. Correspondingly, the child reader may withdraw spiritually from his parents as he feels isolated from them as tries with all his might to reconcile between the two distinct realms. As Bettelheim (1976, 64-65) writes,

Such stories, failing in accord with the child's inner reality, faithful though they may be to external reality, widen the gap between the child's inner and outer experience. They also separate him from his parents, because the child comes to feel that he and they live in different spiritual worlds; as closely as they may dwell in "real" space, emotionally they seem to live temporarily on different continents. It makes for a discontinuity between the generations, painful for both parent and child.

Here Bettelheim makes it clear that problems could occur when the child reader confuses his internal imagination with his external reality. Such is also the conclusion that Margaret Higonnet reaches when she discusses the possible effect that magical characters and events that exist or occur in a realist setting may have on "the child reader...[who] when confronted with violations of the narrative contract, may experience both stimulus and a sense of threat" (Higonnet 1987, 37). It is best, however, to keep in mind that both Bettelheim, a child psychologist and Higonnet are merely postulating on the possible detrimental effects that magic realist literature might have on its readers. To the literacy educationist, Nina Mikkelsen, any text that draws children into reading is beneficial in raising their level of literacy (Mikkelsen 2005, 140). From this, it could well be said that the present studies on the effects that magic realist texts have on the child reader are largely inconclusive and more still needs to be uncovered about the issue, particularly by literacy educators. It would also be wrong to assume that somehow the child reader's psychology would resemble that of the child character or protagonist whom he reads about in a magic realist children's literature. And Anne Hegerfeldt acknowledges this: "Obviously, the child's point of view as it is used in fiction... is very much a construction and should not be confused with psychological reality" (Hegerfeldt 2005, 147). As David Dillon also mentions, "We still know very little about the culture of childhood, what [children's] worlds, constructs and values 
are-which will determine their experience with literature as well as be shaped by it" (Dillon 1985, 166). As their studies have made clear, it is difficult to gauge the impact or role that magic realist children's fiction has on the child reader. A more replicable method of studying this type of literature is by focussing on identifying characteristics of magic realism. Whilst some studies (Head 1996; Norton 1998; Turner 1999) have discussed magic realism in connection with children's fiction, to my knowledge, there has only been a very limited number of sustained and rigorous studies on analysing elements of magic realism in fiction that are meant for children. From these, Don Latham (2006) and Ian Rudge (2006) stand out for their analysis of elements of magic realism in children's fiction. From the two, only Rudge (2006) explores directly the theoretical aspects of this narrative style. While the title of Guldager's (2012) paper appears to focus on magic realism in Rushdie's two children stories, he does not directly address it, focussing instead on the concept of hybridity. To address these shortcomings, this paper seeks to contribute to this understudied feature of magic realism as highlighted in Hegerfeldt's Lies that Tell the Truth: Magic Realism seen Through Contemporary Fiction from Britain (2005) onto its readings of Haroun and The Sea of Stories (1990) by Salman Rushdie.

The application of Hegerfeldt's framework in identifying elements of magic realism in Rushdie's children's novel is principally brought about by the fact that there is no known theoretical framework, before or since the publication of Hegerfeldt's seminal work, which has ever attempted to provide a critically rigorous definition for magic realism. This is understandable since the term "magic realism" has so far been difficult to define and has been for so long subjected to misunderstandings and wrongful applications. In Hegerfeldt's ground breaking book Lies that Tell the Truth (2005) these problems relating to the term are addressed. It has so far provided the most comprehensive and precise elements of magic realist writing that takes a story beyond the boundaries of the commonplace fantasy fiction by delineating, under very precise terms, its characteristics. On whether magic realism in children's fiction would defer markedly from those in adult fiction, to my knowledge, there is very little support for this assumption. In fact, it could be said that the line that demarcate magic realism in children's fiction from that found in adult's fiction is almost non-existent since both primarily deal with conjuring an alternative view of reality that challenges the conventional one.

\section{Salman Rushdie and Magic Realism}

Because his novels are mostly characterised as magic realist, Rushdie's creative writings has provided ample ground for critics to analyse the various issues connected to magic realism. The claim that Bowers (2004) makes regarding Rushdie being the best-known magic realist writer in the English language (45) is 
substantiated by the publication of his highly-acclaimed novels, such as Midnight's Children (1981). Aside from writing adult fiction, Rushdie has also written two children's books, namely Haroun and the Sea of Stories and Luka and the Fire of Life (2010). To many, including Rushdie, magic realism is a narrative style that carried with it an alternate view of reality. More than this, it is a means of telling the truth since some parts in a magic realist text should, he argues, have a meaningful connection to the real world (Fallon 2015). While studies on Rushdie's use of magic realism have so far covered his adult fiction, these have largely ignored his children fiction. An exception to this would be Guldager's (2012) article but even he does not specifically address the different aspects of magic realism. One reason for this may go back to Rushdie's own initial assertion that magic realism allows his readers to experience a different view of reality and not on whether this view is desirable or not as stated within the available literature on children's mental growth. At this point, it is useful to quote the way Rushdie himself expresses support for this:

[The] idea - the opposition of imagination to reality, which is also of course the opposition of art to politics - is of great importance, because it reminds us that we are not helpless; that to dream is to have power [...] Unreality is the only weapon with which reality can be smashed. (Rushdie 1992, 122)

This is obviously a very controversial stand to take in relation to children's literature since the nature of this genre has always been didactic, that is subject to parental regulations and will to control's the way children think and behave. Magic realism defies this parental control because imagination is given free rein over children's minds.

This study employs Hegerfeldt's (2005) categorisation of elements in "magic realism" in its analysis of Rushdie's Haroun and the Sea of Stories in order to overcome various problems that are associated with the term. Initially "magic realism" referred to an artistic mode that originated during the early 1920s. Since then it has undergone various transformations, all of which have resulted in it becoming a distinctive literary mode. Unfortunately, due to its convoluted history and various misapplications, particularly in cases where it is used to refer to fictional writings that feature magical happenings, magic realism in literature is often confused with its original artistic mode and other modes, like the Latin American lo real maravilloso (or "marvelous realism"), as well as other literary genres, such as fantasy fiction, science fiction and fairy tale (Faris 1995, 191-208). Due to the confusion that still surrounds this term, this study refers to the most comprehensive study to date on magic realism, Hegerfeldt's Lies that Tell the 
Truth (2005), for a clear and working definition of the term. It applies five literary features that, according to Hegerfeldt, could be found in magic realist writings in its study of Haroun and The Sea of Stories. These five techniques or features are namely: a realist mode of writing to describe fantastic elements, an "ex-centric" or marginalised focaliser, subverted scientific and historical discourses, a supernatural reality and a literal manifestation of a figurative expression. Before we proceed any further, there is a need to present a short synopsis of the novel in order to get a clearer picture of events that happen in the narrative.

Haroun and the Sea of Stories is the story of a boy, Haroun Khalifa, who lives in a city plagued by so much sadness that its inhabitants have gradually forgotten its name. The city is located in a country called Alifbay. The boy's father, Rashid Khalifa, is a storyteller, famously known as "the Ocean of Notions" among his admirers and "the Shah of Blah" among his enemies. Whenever he tells his stories, Rashid brings magic to the world and it is enjoyed not just by the children and adults in the novel but also the animals in the narrative. The conflict of the story begins when Soraya, Haroun's mother, runs away with their neighbour, $\mathrm{Mr}$ Sengupta, a man who lacks the ability to imagine and who constantly criticises Rashid for the very same reason. Frustrated, Haroun blames his father for his mother's abandonment of their family and accidentally asks Rashid a question that robs the latter temporarily from his ability to tell stories: "What's the use of stories that aren't even true?" (p. 22). To alleviate his guilt and to restore things back to their normal state, Haroun travels to the City of Gup, which is located on the earth's second moon, Kahani, to make a request to the Walrus to restore his father's storytelling ability. Haroun's simple quest to help his father turns into a rescue mission to save the Ocean of the Streams of Story, from whence his father's stories originate, as he decides to help his new magical friends in their effort to stop Khattam-Shud from poisoning the Sea of Stories.

\section{Haroun and the Sea of Stories and the Rushdie Affair}

On the surface, the story contains a simple plot fit for a children's novel. Yet under close reading, it could be said to allude to the political implications behind the publication of The Satanic Verses (1988). Like Rushdie's other magic realist novels, Haroun and the Sea of Stories also tries to capture, metaphorically, "the sweep and chaos of contemporary reality, [in] its resemblance to a dream or nightmare" (Kakutani 1989). This nightmare, in the context of the author's life, refers to his personal plight when he was sentenced to death by the well-known Iranian leader, Ayatollah Khomeni (1900-1989), as the result of the publication of The Satanic Verses and, hence, was forced to seclude himself for nearly a decade. Although Rushdie refrains from associating Haroun and the Sea of Stories with what is now 
known as the Rushdie Affair, his novel cannot be fully understood without taking into account the context of its publication. As pointed out by Jean-Pierre Durix, the novel does contain allusions to "the fight between the imagination, the forces of freedom and those of obscurantism" (Durix 1993, 114). Therefore, Haroun and the Sea of Stories may be read as an attempt by Rushdie to address this issue by using magic realism as an alternative approach to defend stories and storytelling as well as the freedom of speech.

\section{Realist Narrative Technique}

Although the opening of the novel, "There was once, in the country of Alifbay, a sad city, the saddest city..." (p. 15) seems to impose a fairy tale-like structure on the narrative, Haroun and the Sea of Stories contains all the magic realist features listed by Hegerfeldt. The first magic realist feature that can be found in the novel is the appropriation of a realist narrative technique, in particular, a nonchalant narrative tone, to describe magical characters and fantastic events in the novel. The use of this technique results in undermining realism as a privileged mode of writing since it shows that a magic realist narrative can also be set in a realistic world or setting. However, within this magic realist context, conventional values and norms are marginalised in favour of those that are fantastic. Magic realism, hence, advocates an alternative point of view about reality that is different from that held by the dominant centre. This is supported by Zamora and Faris $(1995,3)$ who claim that magic realist texts draw upon cultural systems that are as real as those represented by literary realism and frequently these "privilege mystery over empiricism, empathy over technology, tradition over innovation".

The appropriation of a realistic setting is the most apparent aspect of magic realism in Haroun and the Sea of Stories. This technique aims to manipulate the reader's sense of familiarity to places in the real world. This, according to Bortolussi (2003, 350 ), allows readers to distinguish magic realist texts from either fantasy fiction or science fiction because the settings of the last two genres are distinctly fantastical. There are two dominant settings that can be identified in Haroun and the Sea of Stories. The first is the planet earth, which consists of, amongst other places, the "imaginary" country of Alifbay, the Town of G as well as the Valley of K, which is nestled in the Mountain of M where a beautiful lake called Dull exists. The second setting takes place outside of the planet earth itself, on the earth's second moon, Kahani, which is made up of a vast Ocean of the Streams of Story, Gup City, Twilight Strips where Chattergy's Wall that separates Gup City from the Chup City stands and finally, Chup City. As indicated by the descriptions of these places in the novel, the first setting represents the extratextual real world, while the second one is a magical place located outside of the planet earth itself. 
The most obvious reference to the real world, as mentioned by Durix (1993), could be found in a reference made in chapter two of the novel to Valley of K, or Kache$\mathrm{Mer}$, which clearly alludes to Kashmir, a northern state in India. This connection is reinforced through the narrative's geographical description of a valley that is filled with gold and located near a mountain of silver. In reality, the "gold" that fills Kashmir valley, or the Valley of K, comes from a plant called saffron crocus that is planted in the valley and from which the precious saffron spice is produced and the silver mountain refers to the Himalayan ranges that are located in the state and are covered in snow. Dull Lake also alludes to Dal Lake in Kashmir, with its shoreline, which is made up of floating houseboats and hotels. Correspondingly, the real Dal Lake also has floating gardens for vegetation and these fit the description given by Rashid, "You weave lotus-roots together to make the carpet and then you can grow vegetables right here on the Lake" (p. 43).

Although Durix (1993) argues that the setting for Haroun and the Sea of Stories is not essentially realistic because the story only alludes to one familiar landscape or locale from the real world, which is Kashmir and Lake Dal, there are many allusions in the novel to the real world that enhance the realistic appeal of its settings. These references include common animals, like cows, monkey, parrots, kangaroos; usual occupations, such as milkman, politician and bus driver; ordinary modes of transportation, such as plane, buses, train and boat; as well as well-known places, including goldmines, pagodas, Africa, Mount Fujiyama and the North Pole, which all exist in the real world.

Aside from these references to real places and aspects of life, Alifbay is also anchored to the real world through Rushdie's childhood memory as Suchismita Sen (1995) claims that Rushdie has re-created, in Haroun and the Sea of Stories, the India of his childhood. This is particularly true in his descriptions of the typical middle-class Indian's lifestyle and the Indian English spoken in Bombay in the 1950s and the 1960s (Sen 1995, 662). In one passage, Khalifa's house is described as, "a small concrete house with pink walls, lime-green windows and blue painted balconies with squiggly metal railings" (p. 18). According to Sen $(1995,663)$, this resembles a typical residence of a less-than-fashionable middle-class Indian family while the heated argument scene on the bus that carries Haroun and Rashid to the Valley of $\mathrm{K}$ excellently recaptures a familiar scene in a crowded city bus in a bygone India. As readers read in one passage,

"My holdall," yelled a mud-woman. "Crazy buffalo! Looney tune! Desist from your speeding, or my possessions will be thrown to Kingdom Come!" 


\begin{abstract}
"It is we ourselves who will be thrown, madam," a mud-man answered sharply. "So less noise about your personal items, please." He was interrupted angrily by a second mud-man: 'Have a care! It is my goodwife you are insulting!' Then a second mud-woman joined in: "So what? For so long she has been shouting-shouting in my husband's goodear, so why should not he lodge complaint? See her, the dirty skinnybones. Is she a woman or a muddy stick?"
\end{abstract}

The linguistic expressions and the speakers' communicative strategies, as expressed in the above passage, are clearly those that belong to Indo-English speakers. In the excerpt, the repetition of the verb "shouting" indicates a common behaviour amongst Indo-English speakers when expressing intense emotions, which in this case are annoyance and irritation. At the same time, the words "desist" and "possession" are hardly used by native English speakers in the context of a similar conversation as that described above. According to Sen, the passage also shows speakers resorting to archaic Victorian expressions, such as "goodwife" and "goodear", to politely address certain individuals. This is largely because the English language that was spoken in colonial India had become "fossilised" as a result of its speakers" inability to keep up with its development in Britain (Sen 1995, 664-666). While Rushdie's young readers might not be familiar with these expressions since India has undergone extensive transformation since its independence, Rushdie's Indian contemporaries may recall from these references familiar sights and sounds of everyday Indian life that they once knew as children. Accordingly, since the narrative is also filled with magical characters and happenings, it suggests that these are also part of the same reality as those that could be found in the real world.

Magical creatures and improbable events are also normalised by the novel's omniscient-third-person narrator's casual and nonchalant tone of voice. The normalisation of magical characters and events, which results from this type of narration, is crucial as Bowers $(2004,25)$ claims that unless magical characters and events in a fictional text are made to appear normal and commonplace, the text cannot be called "magic realist" Bowers. This shows the duplicitous nature of magic realism because it undermines both realist and non-realist writing conventions. Consequently, all forms of recontextualisation of magical characters or events either as hallucinations, dream or lies, are prevented as their matter-offactness is reaffirmed by the same techniques used in realist fiction (Habib 2011, 169).

A good example of the use of a nonchalant narration to describe a highly improbable event in the novel is when Haroun decides to embark on a journey to Kahani. 
From the moment Haroun meets Iff, the Water Genie who comes to disconnect the Story Tap from Rashid's subscription, until the father and son return to Alifbay, the narrator continuously maintains a casual and indifferent narratorial voice. For instance, when Haroun first meets Iff in a houseboat on Dull Lake, the narrator is not surprised by the existence of the magical being and casually describes Iff's appearance as he says, "he [Haroun] saw a small, ancient-looking man, no bigger than himself, wearing a huge purple turban on his head...and baggy silk pajamas gathered at the ankles... This little fellow sported an impressive full set of whiskers, of a most unusual color: the palest, most delicate shade of sky blue" (p. 55). Clearly the Water Genie is not described in the novel as either mysterious or peculiar. The narrator also refrains from using any phrases that could produce doubts about the presence of the Water Genie. The casual tone of the narrator renders the existence of Iff as real and reaffirms the matter-of-factness of Haroun's meeting with Iff because the narrator accepts the existence of the Water Genie at face value.

\section{Marginalised Focaliser}

The second magic realist technique in Haroun and the Sea of Stories is the use of a marginalised focaliser. A focaliser, in the structure of a narrative, is an omniscientthird-person narrator who has access to the innermost thoughts and hidden motives of other characters in a story. In Haroun and the Sea of Stories, the omniscientthird-person narrators, the Guppees, express a point of view that is different from the one held by the centre. If the novel were to be taken as an analogy of Rushdie's resistance against the restrictions imposed on creative imagination and the freedom of speech by an Iranian leader, it could be surmised that Ayatollah Khomeini is, in real life, the dominant centre that needs to be resisted by those at the margins. This is because Rushdie, at the time of the publication of the book, was still under the threat of the death fatwa sentenced on him by the Iranian leader. It could be said that in his response to the centre, Rushdie utilises magic realism in Haroun and the Sea of Stories to justify the importance of stories and defend the freedom of speech. This is made possible because a magic realist text, according to Zamora and Faris (1995), provides a space for diverse interaction.

Diverse interactions take place in Haroun and the Sea of Stories because its omniscient focalisers know everything that happens in the novel. Jonathan Culler $(1997,90)$ argues that focalisation in a novel allows the world to be presented from an omniscient point of view because the focaliser has the privilege of knowing all information about events in the story as well as all of the characters' thoughts and actions. Although the marginalised perspective is endorsed in the text, the perspective of the centre remains active. In the novel, the latter is represented by the antagonist of the story, Khattam-Shud, who according to many critics stands 
for Ayatollah Khomeini (Baena 2001; Biscaia 2005; Kullmann 1996; Coppola 1991; Teverson 2001).

Taking into account the context of the publication of the novel, which is the fact that it was published after the Rushdie Affair, the dominant perspective of the centre supports the assertion that Plato makes regarding art and artistes. In The Republic, Plato openly objects to the value of art, including stories, on the basis that they give a false representation of the world because their function is to imitate as he elaborates in Book X of The Republic:

[W]e find three beds, one existing in nature, which is made by God; another which is the work of the carpenter; and a third, the work of the painter or poet. Hence, the carpenter imitates the real bed and the painter or poet imitates the physical bed. The poet's work, then, like that of the rhapsody is the "imitation of an imitation." It is thrice removed from truth. (Habib 2011, 15)

In other words, the work of an artist, according to Plato, diverts his or her audience from the truth because an artist is only able to imitate an imitation. In addition to this, Plato also views stories as dangerous because they have the power to change public opinion. This idea in Haroun and the Sea of Stories is clearly demonstrated by both Mr Sengupta and Khattam-Shud, as they share a similar hatred towards stories. Mr Sengupta's criticism of Rashid's storytelling abilities clearly resembles Plato's disregard for the value of stories as he claims that they are useless and unbeneficial to society, as the former says, "What are all these stories? Life is not a storybook or a joke shop. All this fun will come to no good. What's the use of stories that aren't even true?" (p. 20). In fact it is Mr. Sengupta who is the first to ask the question, "What's the use of stories that aren't even true?", which in turn leaves Haroun's doubtful of his father's talent as the former begins to ask the very same question to the latter, causing him to lose his storytelling gift. Furthermore, this idea about censorship as detrimental to the fostering of creative forms of expression is echoed in the rationale that Khattam-Shud gives for wanting to destroy the Ocean of the Streams of Story:

"But why do you hate stories so much?" Haroun blurted, feeling stunned.

"Stories are Fun..."

"The world, however, is not for Fun," Khattam-Shud replied. "The world is for Controlling."

“Which world?" Haroun made himself ask. 
"Your world, my world, all worlds," came the reply. "They are all there to be Ruled. And inside every single story, inside every Stream in the Ocean, there lies a world, a story-world, that I cannot Rule at all. And that is the reason why." (p. 161)

In the above-mentioned excerpt, the capitalisation of verbs such as "Controlling", "Ruled" and "Rule" emphasises the extreme forms of censorship that stories sometimes are subjected to in order to be heard or published. It could also be inferred from this passage that Khattam-Sud's desire to control stories harks back to Plato's argument that stories are able to change public opinion. Although stories are created from an individual's imagination, some of them contain narrative knowledge that can help their readers to better understand the latters' own real-life problems through identification with situations presented in the stories. The novel contains an example of this as when the people in the Valley of $\mathrm{K}$ revolt against Snooty Buttoo, a tyrannical politician. It would not be too difficult to imagine how much the novel's readers, who could themselves be ruled by an unjust ruler, would be able to identify with the misery felt by the oppressed Chupwalas.

In Haroun and the Sea of Stories, Plato's idea is challenged by the words and actions of the Guppees, the marginalised focaliser in the story. The Guppees believe in ideas about stories that deviate from those held by the centre because they view stories as an important medium of entertainment and a source of inspiration. Despite their highly advanced technology, the Guppees believe in the magic of stories. Stories, to the Guppees, are not useless because they can meaningfully affect the life of their readers and listeners. This is demonstrated by Iff, who wishes to restore Haroun's spirit after he fails to make a wish over the Wishwater. Iff masterfully catches a single and pure Stream of Story from the Ocean entitled Princess Rescue Story Number S/1001/ZHT/420/41(r)xi and offers it to Haroun for him to drink it for "the magic of story can restore his spirits" (p. 72). Having drunk the liquid, he immediately undergoes an adventure fit for a conventional hero as "[h]e was, so to speak, looking out through the eyes of the young hero of the story" (p. 73). If he did not drink the poison that is polluting the Ocean, Haroun would have met with a happy ending as he would have become the typical romantic hero who rescues a princess and walks off into the sunset. This happy ending would have restored his spirit from its miserable failure to concentrate on an object or a task for more than eleven minutes. From this episode, the novel indicates that even a simple fairy tale, like Princess Rescue Story Number S/1001/ZHT/420/41(r)xi, can bring joy to its hearers. 


\section{Subverted Scientific Discourse}

In a magic realist text, such as Haroun and the Sea of Stories, non-literary discourses, in particular those on natural science, are subverted in order to emphasise the importance of narrative knowledge as a valid mode for understanding reality. This aims to demonstrate that science alone cannot provide a comprehensive explanation of the world. Since the middle of the seventeenth-century, during the age of the Enlightenment (1650-1800) and at the beginning of the Early Modern period (1450-1750), western thought and culture had undergone rapid development in the fields of science, technology, philosophy, politics and economy. During this period, the feudal system that was characterised by the medieval worldview was displaced by ideals propagated by the Enlightenment, particularly concerning the limitless potential of human reason and sense perception as the primary faculty for acquiring knowledge. As a result of the scientific revolution pioneered by Sir Francis Bacon (1561-1626), modern science became the primary method for obtaining knowledge. Because they regarded natural science as the dominant authority for providing knowledge about the world, the Enlightenment thinkers rejected narrative knowledge that is derived from tradition, myth, legends and superstition because these, according to them, could not be proven to be scientifically valid. Yet sustained reliance on such a discourse in many societies could be traced to common beliefs that are shared collectively by a community (Zamora and Faris 1995, 3).

Challenging scientific discourse's ability to provide its readers with a comprehensive understanding of the world, Haroun and the Sea of Stories has characters who adhere to the scientific principle but resort to "mock-scientificdiscourse" to explain their scientific achievements. An example of this in the novel is the marginalised focalisers, the Guppees, who are practitioners of science but use unscientific methods to protect their stories. Readers are told that all the stories that are stored in the Ocean of the Streams of Story are held in liquid form and these could be mixed and transformed to become new versions of them. Because of this the Ocean of the Streams of Story could be said to symbolically represent a pool of collective narrative knowledge that includes all forms of stories, such as myth, legends and fairy tales that are often excluded from our understanding of reality. This symbolism becomes more apparent when the existence of the Ocean is kept hidden from being discovered through the use of an advanced technology and forms of belief that relegate the existence of the Ocean to the level of myth. Interestingly, the Ocean of the Streams of Story is the title of a book consisting of a collection of tales by Somadeva (c. 1070), a Kashmiri Brahman who was a writer of Sanskrit as well as a court poet to King Ananta of Kashmir and whose job was to preserve much of India's ancient folklore in the form of a series of tales. 
Through the Guppees, "mock-scientific-discourse" is used to establish narrative knowledge as an important source of knowledge. Through Butt, the voice of the "ultra-rational" (71), mock-scientific discourse appears in the form of metafictional comments made by a telepathic flying machine. As Butt, in a scientific tone, explains to Haroun the means to conceal the moon, Kahani, from being discovered:

But but but it is because of Speed ... --Speed, super Speed! If not for the Speed of Light, the universe would be dark and cold. - But if Speed brings light to reveal, it can also be used to conceal. The Moon, Kahani, travels so fast -wonder of wonders! - that no Earth instruments can detect it; also its orbit varies by one degree per circuit, so that in three hundred and sixty orbits it has overflown every spot upon the Earth. Variety of Behavior assists is Evasion of Detection. But also, there are serious purposes for the variation of orbit: Story Water facilities must be provided across the entire planet with an even hand. Voom! Varoom! Only at High Speed may this be done. You appreciate the further bonuses of Machines? (p. 67)

The use of scientific language in the above passage, such as "instrument", "one degree per circuit", "orbits", "Variety of Behavior" and "Evasion of Detection", lend scientific credibility to Butt's explanation. Yet it also undermines scientific discourse because science is used to verify the occurrence of a highly remarkable fantastic event. Moreover, the passage above also implies that not all existences or occurrences could be discovered using empirical methods since some need to be blindly acknowledged as existing or occurring.

Despite being in possession of a highly advanced technology, the Guppees and those who live in their world, such as Iff, have a natural inclination to believe in magic. Iff, remarking on Haroun's reliance on his senses to verify the existence of matter, asks the latter:

How much have you seen, eh, Thieflet? Africa, have you seen it? No? then is it truly there? And submarines? Huh? Also hailstones, baseballs, pagodas? Goldmines? Kangaroos, Mount Fujiyama, the North Pole? And the past, did it happen? And the future, will come? Believe in your own eyes and you'll get into a lot of trouble, hot water, a mess. (p. 63) (Author emphasis in italic)

This excerpt is an example of how scientific discourse could be undermined when it is viewed as an unreliable source for verifying truth and existence since it is heavily restricted by limitations of the human senses and empirical methods. This is because some matters, such as events that had happened in the past, could hardly 
be verified in an objective manner. An example of this is the fact that while physical evidences lend legitimacy to studies on history, historians use as tools subjective narratives to interpret discovered objects and signs. Likewise, the likelihood that a single event will take place in the future cannot be confirmed using a scientific hypothesis or a set of assumptions.

\section{Supernatural Reality}

Aside from being viewed as insufficient to explain reality, science and technology in Haroun and the Sea of Stories are supernaturalised, or made to appear supernatural, in order to make them seem remarkable or fantastic. The narrative, at the same time, also poses ethical questions concerning their use and abuse. In the novel, aside from the Guppees who have mastered the technology to build P2C2E, Khattam-Shud also possesses an advanced technology that is described by Iff as "Far Too Complicated to Explain" (p. 159). He, however, uses his scientific knowledge and technological know-how to destroy stories instead of protecting them. Like a typical scientist, Khattam-Shud experiments and discovers a method to "synthesise" poisons that could be used to destroy every stream of stories in the Ocean. On a dark ship, which is his laboratory, Khattam-Shud mixes some "antistory" poisons using a machinery that is "Far Too Complicated to Explain", which is also known as "The Poison Blenders" (p. 159). In fact, in order to nip his problem in the bud, Khattam-Shud assembles the largest and most efficient Plug to block the Wellspring of the Ocean, which is the source of the stories, from pouring out new stories into the Ocean. It could be inferred from this that Khattam-Shud takes Bacon's famous dictum "Knowledge is Power" literally as he misuses science and technology in order to cause destruction and, by doing so, draws attention to the ethical issues concerning their limits and abuses.

Khattam-Shud, however, is not the only person who misuses technology as the Guppees also indirectly manipulate it in order to oppress the Chupwalas by creating a device that controls Kahani's rotation, an act that results in endless days in the Land of Gup and perpetual nights in the Land of Chup. They have also built an unbreakable and invisible Wall of Force, known as Chattergy Wall, which completely separates the two lands. Because of this, the Chupwalas, including those who disagree with Khattam-Shud, are forced to stay in their land and obey the Silence Laws enforced by the latter. The Guppees, however, are indifferent to the consequences of technology abuse as Butt casually and proudly informs Haroun about the Eggheads' achievement:

"Thanks to the genius Eggheads at P2C2E house," Butt began, taking pity on Haroun, "the rotation of Kahani has been brought under control. 
As a result, the Land of Gup is bathed in endless Sunshine, while over in Chup it's always the middle of the night. In between the two lies the Twilight Strip, in which, at the Grand Comptroller's command, Guppees long ago constructed an unbreakable (and also invisible) Wall of Force. Its goodname is Chattergy's Wall, named after our King, who of course had absolutely nothing to do with building it." (p. 80)

As the excerpt indicates, Butt indirectly supernaturalises science and technology with the help of the Eggheads, in order to oppress the Chupwalas, who are seeking refuge from Khattam-Shud's tyranny, by blocking their escape to other places. This episode is a good example of the need to rely on a code of ethics to regulate scientific research, as its misuse could result in gross injustice to members of a society. Additionally, other passages also show how the misuse of science and technology results in the importance of narrative knowledge being undermined. Using their machines, P2C2E and M2C2D, the Guppees cause the moon, Kahani, to rotate at such an incredible speed that it virtually disappears from sight. The only way for Haroun to know that it exists is when its existence is mentioned by a few practitioners of the oral tradition, such as storytellers. Haroun, however, is aware that most people would not believe in the truth value of stories as he admits that since "stricter rules apply" (p. 63) on earth in relation to knowledge acquisition, oral tradition passed down by storytellers, like Rashid, is downgraded as myth and superstition.

\section{Literalisation}

The last magic realist feature that can be identified in Haroun and the Sea of Stories is the literal manifestations of figurative expressions or literalisation. In the novel, it appears primarily in the form of a formidable question, "What's the use of stories that aren't even true?", a question that Haroun poses to his father after his mother, Soraya, leaves the family. Soon afterwards the unthinkable happens to Rashid: "Rashid Khalifa, the legendary Ocean of Notions, the Fabled Shah of Blah, stood up in front of a huge audience, opened his mouth and found that he had run out of stories to tell"' (p. 22). The question works like a curse, condemning Rashid's mind into thinking that he is useless and strips away his storytelling ability. It sets in motion the rest of the story as Haroun blames himself for his father's misfortune and is willing to go to Kahani to restore his father's Streams of Story subscription. By turning the question into a cause of misfortune, magic realism emphasises that words can also have as much impact as actions. 


\section{Conclusion}

Displaying all five prototypical magic realist features outlined by Hegerfeldt in Lies that Tell the Truth, Haroun and the Sea of Stories is Rushdie's masterful creation of a magical world that could well be the real world through its appropriation of a realist mode of writing to describe magical events and characters. Realism, as a privileged mode of representing reality in fiction, is undermined since the narrative shows that it can also be used to describe magical happenings as well as characters. Moreover, in order to present an alternative perspective that is derived from the margin, marginalised focalisers are used in the novel. While narrative knowledge, which is derived from myths, legends and oral traditions, is considered as an important source of knowledge in the novel, science is made to appear as supernatural. Finally, the novel also employs literalisation as a figurative expression becomes manifested literally. Overall, it could be said that Haroun and the Sea of Stories is a magic realist fiction as many of its features bring its readers to see the real in the magic.

\section{Bibliography}

Baena, R. 2001. Telling a bath-time story: Haroun and the Sea of Stories as a modern literary fairy tale. Journal of Commonwealth Literature 36(2): 65-76.

Bettelheim, B. 1976. The uses of enchantment: The meaning and importance of fairy tales. London: Penguin.

Biscaia, M. 2005. Desire and ideological resistance: Fabulation in Haroun and the Sea of Stories. In Forma breve 3 revista de literatura: A fảbula, eds. O.P. Monteiro, F.S. Silveira, E. Lisboa, D.H. Pageaux, R.M. Goulart, F.C. Fagundes, J.R. Castillo, R.P. Garay and J.M. Rodrigues Filho. Santiago, Aviero: Universidade San Aviero, 239-250.

Bortolussi, M. 2003. Implausible worlds, ingenuous narrators, ironic authors: Towards a revised theory of magic realism. Canadian Review of Comparative Literature 30(2): 349-370.

Bowers, M.A. 2004. Magic(al) realism. Abingdon, Oxon: Taylor and Francis e-Library.

Coppola, C. 1991. Salman Rushdie's Haroun and the Sea of Stories: Fighting the good fight or knuckling under. Journal of South Asian Literature 26(1/2): 229-237.

Culler, J. 1997. Narrative. In Literary theory: A very short introduction, ed. J. Culler, 8293. New York: Oxford University Press Inc.

Dillon, D. 1985. Quoted by G. Boomer. In Language, schooling and society, ed. S. Tchudi. Montclair, NJ: Boynton/Cook.

Durix, J.P. 1993. The gardener of stories: Salman Rushdie's Haroun and the Sea of Stories. Journal of Commonwealth Literature 28(1): 114-122.

Fallon, C. 2015. Salman Rushdie on magical realism, Twitter and his new novel. Huffington Post, 9 September. http://www.huffingtonpost.com/entry/salman-on-hisnewnovel_ us_55ef2dabe4b03784e276c430 (accessed 1 January 2016). 
Guldager, M. 2012. Magical realism and hybridity: Salman Rushdie's Haroun and the Sea of Stories \& Luka and the Fire of Life. https:/www.academia.edu/29393274/ Magical_Realism_and_Hybridity_Salman_Rushdies_Haroun_and_the_Sea_of_ Stories_and_Luka_and the Fire_of_Life (accessed 20 September 2018).

Faris, W.B. 1995. Scheherazade's children: Magical realism and postmodern fiction. In Magical realism: Theory, history, community, eds. L.P. Zamora and W.B. Faris, 163-190. Durham, North Carolina: Duke University Press.

Habib, M. 2011. Literary criticism from Plato to the present. Chicester, UK: WileyBlackwell.

Head, P. 1996. Robert Cromier and the postmodernist possibilities of young adult fiction. Children's Literature Association Quarterly 21(1): 28-33.

Hegerfeldt, A.C. 2005. Lies that tell the truth: Magic realism seen through contemporary fiction from Britain. Amsterdam: Rodopi.

Higonnet, M.R. 1987. Narrative fractures and fragments. Children's Literature 15: 37-54.

Kakutani, M. 1989. Critic's notebook: Telling truth through fantasy; Rushdie's magic realism.

The New York Times, 24 February. https://www.nytimes.com/books/99/04/18/ specials/rushdie-realism.html.

Kullmann, T. 1996. Eastern and western story-telling in Salman Rushdie's Haroun and the Sea of Stories. Erfurt Electronic Studies in English EESE 1/1996.

Mikkelsen, N. 2005. Powerful magic: Learning from children's responses to fantasy literature. New York: Teacher's College, Columbia University.

-1999. Words and pictures: Lessons in children's literature and literacies. New York: McGraw-Hill.

Norton, L. 1998. Seeing is believing: Magical realism and visual narrative in Margaret Mahy's The Changeover. Bookbird 36(2): 29-32.

Latham, D. 2006. Magical realism and the child reader: The case of David Almond's Skelling. The Looking Glass: New Perspectives on Children's Literature 10(1): n.p.

Rudge, I. 2006. Magic realism in children's literature: A narratological reading. New Review of Children's Literature and Librarianship 10(2): 127-140.

Rushdie, S. 1998. The satanic verses (1988). London, England: Knopf.

-1992. Imaginary homelands. London: Penguin Books. . 1990. Haroun and the sea of stories. Great Britain: Granta Books.

Teverson, A.S. 2001. Fairy-tale politics: Free speech and multiculturalism in Haroun and the Sea of Stories. Twentieth-Century Literature 47(4): 444-466.

Turner, H. 1999. Realism, magic and magical realism (for those upon whom such distinctions are lost). Canadian Children's Literature 93: 60-62.

Zamora, L.P. and Faris, W.B. 1995. Introduction: Daiquiri birds and Falubertian parrot(ie) s. In Magical realism: Theory, history, community, eds. L.P. Zamora and W.B. Faris, 1-14. Durham, North Carolina: Duke University Press. 